\title{
An Antarctic stratigraphic record of stepwise ice growth through the Eocene-Oligocene transition
}

\author{
Sandra Passchier ${ }^{1}$, Daniel J. Ciarletta ${ }^{1}$, Triantafilo E. Miriagos ${ }^{1}$, Peter K. Bijl ${ }^{2}$, Steven M. Bohaty ${ }^{3}$ \\ ${ }^{1}$ Department of Earth and Environmental Studies, Montclair State University, 1 Normal Ave, Montclair \\ NJ, 07043, U.S.A., passchiers@mail.montclair.edu \\ ${ }^{2}$ Department of Earth Sciences, Faculty of Geoscience, Utrecht University, Heidelberglaan 2, 3584CS \\ Utrecht, The Netherlands \\ ${ }^{3}$ Ocean and Earth Science, University of Southampton, National Oceanography Centre Southampton, \\ 20 European Way, Southampton SO14 3ZH, UK
}

\begin{abstract}
Earth's current icehouse phase began $\sim 34$ million years ago with the onset of major Antarctic glaciation at the Eocene-Oligocene Transition (EOT). Changes in ocean circulation and a decline in atmospheric greenhouse gas levels were associated with step-wise cooling and ice growth at southern high latitudes. The Antarctic cryosphere plays a critical role in the ocean-atmosphere system, but its early evolution is still poorly known. With a near-field record from Prydz Bay, Antarctica, we demonstrate that Antarctic ice growth was stepwise and had an earlier onset than previously suggested. Prydz Bay lies downstream of a major East Antarctic ice-sheet drainage system and its sedimentary records uniquely constrain the timing of ice-sheet advance onto the continental shelf. We investigate a detrital record extracted from three Ocean Drilling Program drill holes within a new depositional and chronological framework spanning the late Eocene to early Oligocene ( $36-33 \mathrm{Ma})$. The chemical index of alteration (CIA) and the S-index, calculated from the major element geochemistry of bulk samples, yield estimates of chemical weathering intensities and mean annual temperature (MAT) on the East Antarctic continent. We document evidence for late Eocene mountain glaciation along with transient warm events at 35.8-34.8 Ma. From 34.4 Ma, associated with the EOT-1 $\delta^{18} \mathrm{O}$ excursion, glaciers advanced into Prydz Bay, coincident with a decline in chemical weathering and temperature. We conclude that Antarctic continental ice growth commenced with the EOT-1 "precursor" glaciation, during a time of Subantarctic surface ocean cooling and a decline in atmospheric $\mathrm{pCO}_{2}$. These results call for dynamic high-latitude feedbacks that are currently poorly represented in Earth system models and emphasize the need for additional near-field glaciosedimentological, high-latitude SST, and $\mathrm{pCO}_{2}$ records across the EOT.
\end{abstract}

\section{INTRODUCTION}

The Eocene-Oligocene transition (EOT) at $\sim 34 \mathrm{Ma}$ marks the onset of continental-scale Antarctic glaciation, but questions remain about the exact mechanisms involving ice sheet formation and the dynamics of ice growth during this time. Based on deep-sea proxy evidence, the onset of Antarctic glaciation most likely occurred in steps (Coxall et al., 2005; Coxall and Wilson, 2011). Benthic foraminiferal oxygen isotope $\left(\delta^{18} \mathrm{O}\right)$ records coupled with sea level and paleotemperature proxies suggest that a first $0.5 \% \circ \delta^{18} \mathrm{O}$ step at the EOT was primarily an effect of cooling, with a small ice-volume component, whereas the second, larger $\delta^{18} \mathrm{O}$ step (Oi-1) was predominantly an ice volume signal (Lear et al., 2008; Katz et al., 2008). Maximum glaciation appears to have been a climatic overshoot as benthic $\delta^{18} \mathrm{O}$ values gradually rebounded (decreased) following the Oi-1 excursion (Zachos and Kump, 2005). Although the magnitude of the Oi-1 benthic stable oxygen isotope shift is consistent through the ocean basins, there is uncertainty regarding the degree, timing, and spatial variability of deep-water temperature change, which translates into uncertainties in ice volume estimates (e.g., Bohaty et al., 2012). 
Furthermore, ice sheets are currently not fully coupled in Earth system models, which limits the understanding of Antarctic ice sheet - atmosphere - ocean feedbacks at the onset of the icehouse phase (DeConto and Pollard, 2003; Zachos and Kump, 2005; Miller et al., 2009; Goldner et al., 2014; Ladant et al., 2014).

Despite the importance of the EOT interval, detailed insights into the timing and paleoenvironmental implications of ice growth close to the locus of ice formation on Antarctica are sparse (e.g., Galeotti et al., 2016). Recent improvements of age control and collection of new sedimentological and geochemical data allow us to characterize the onset and extent of ice growth on the Antarctic margin in unprecedented detail within a ca. $400 \mathrm{~m}$ thick sequence drilled by the Ocean Drilling Program (ODP) in Prydz Bay (Figures 1 and 2). Here, we interpret a record of detrital sediment delivery to the Antarctic continental shelf that carries the signature of late Eocene-to-early Oligocene high-latitude climate and ice sheet variability.

Prydz Bay lies on the passive margin of East Antarctica downstream of the Lambert Graben that carries the largest ice stream in East Antarctica. The Gamburtsev Mountains, upstream from the Lambert Graben, are regarded as one of the first nucleation points of East Antarctic glaciation (DeConto and Pollard, 2003; Rose et al., 2013). Glaciation of the Gamburtsev Mountains commenced with ephemeral cirque glaciers (Bo et al., 2009). Following the cirque glaciation, alpine glaciers eroded overdeepenings into the Gamburtsev Province likely over a short period of 0.3-3.0 Myr prior to development of a persistent cold-based ice cover at high elevation (Rose et al., 2013). The timing of the landscape and ice sheet evolution, however, is poorly constrained with regional paleoenvironmental data.

Three ODP drill holes at Sites 739, 742 and 1166 were drilled in 400-500 m water depth in Prydz Bay and, together, provide a detailed record of the Eocene-Oligocene transition in East Antarctica. The timing and position of Oi-1 were recently constrained with dinoflagellate cyst biostratigraphy in Hole 739C (Houben et al., 2011, 2013), which allows us to further refine the age model for these sites. At all three sites, the Eocene-Oligocene intervals were identified deeper than $\sim 135 \mathrm{mbsf}$, and the mud-rich consolidated sediments were relatively well-recovered by rotary drilling at these depths. For the first time, we evaluate lithofacies using one classification scheme that is the same for all drill holes. Previously published sedimentological descriptions were carried out only as part of shipboard analysis during ODP Legs 119 and 188 (Hambrey et al., 1991; Shipboard Scientific Party, 2001). We calculate the Chemical Index of Alteration (CIA; Nesbitt and Young, 1982) to characterize paleo-weathering conditions and the S-index (Sheldon et al., 2002) to reconstruct continental surface temperatures. Our new data and stratigraphic framework along with recently published detrital geochemical data for the same and nearby cores (Cox et al., 2010; Scher et al., 2011; Tochilin et al., 2012; Thomson et al., 2013) allow us to reconstruct late Eocene-earliest Oligocene climate variability and stepwise glaciation of East Antarctica.

\section{METHODS}

\section{Materials and analytical methods}

New sedimentological logging and descriptions of the ODP 739C, 742A, and 1166A drillholes were carried out on the archive halves at the International Ocean Discovery Program (IODP) Gulf Coast Repository in 2013. Previous descriptions carried out during shipboard core characterization in 1988 and 2000 did not apply the same classification schemes. Our lithofacies designations were based on the classifications of Mazullo and Graham (1988) and Moncrieff (1989). Particle size distributions were collected on the matrix $(<2 \mathrm{~mm}$ ) of 253 samples from Holes $739 \mathrm{C}, 742 \mathrm{~A}$ and $1166 \mathrm{~A}$, using a Malvern Mastersizer 2000 laser particle size analyzer (Ciarletta, 2014). Using these data, 52 samples from Holes $739 \mathrm{C}$ and $742 \mathrm{~A}$ with more than $60 \%$ mud fraction were prepared for Inductively Coupled Plasma-Atomic Emission Spectroscopy (ICP-AES) analysis of the bulk rock. Geochemical data for Hole 1166A were previously published in Passchier et al. (2013). Sample preparation involved mixing $0.1 \mathrm{~g}$ of sample with 
$0.4 \mathrm{~g}$ of $\mathrm{LiBO}_{4}$ flux, fusion in a furnace at $1050^{\circ} \mathrm{C}$, and dissolution of beads in $7 \% \mathrm{HNO}_{3}$ (Murray et al., 2000). Diluted samples were analyzed for 10 major elements on a Jobin Yvon ICP-AES using 10 USGS standards. Reproducibility is typically $1-5 \%$ for major elements, except $P(5-13 \%)$. CIA values were calculated according to Nesbitt and Young (1982) as $100 \mathrm{x}$ the molar ratio of $\mathrm{Al}_{2} \mathrm{O}_{3}$ to $\mathrm{Na}_{2} \mathrm{O}, \mathrm{CaO}^{*}, \mathrm{~K}_{2} \mathrm{O}$ and $\mathrm{Al}_{2} \mathrm{O}_{3}$, where $\mathrm{CaO}^{*}$ designates $\mathrm{CaO}$ in detrital silicate minerals only. Calcium carbonate percentages of the sediments analyzed in Holes $739 \mathrm{C}$ and $742 \mathrm{~A}$ were $<2 \%$ (Barron et al., 1989) and no corrections were applied. CIA analyses are reproducible within one CIA unit. The temperature climofunction applied is based on the S-index from Sheldon et al. (2002), which is defined as the molar ratio of $\mathrm{Na}_{2} \mathrm{O}$ and $\mathrm{K}_{2} \mathrm{O}$ to $\mathrm{Al}_{2} \mathrm{O}_{3}$. The Mean Annual Temperature (MAT) calibration of the S-index has a $1-\sigma$ uncertainty of $3.6^{\circ} \mathrm{C}$ (Sheldon et al., 2002). All instrumental analyses were carried out at Montclair State University.

\section{Application of the CIA and S-index as weathering proxies}

The CIA was developed as a continental weathering proxy applied to mudrocks sourced from glaciated drainage basins (Nesbitt and Young, 1982) and can be applied to basins that are weathering-limited, with high erosion and sediment transport rates and short-term floodplain storage (Passchier et al., 2013). Under these conditions, the release of the cations $\mathrm{Ca}, \mathrm{Na}, \mathrm{K}$, and $\mathrm{Al}$ from silicate minerals is primarily controlled by the surface temperature and precipitation regime. Cation release from mineral surfaces decreases exponentially within a few thousand years of exposure during which time mineral surfaces become increasingly less reactive (Egli et al., 2001). Thus, upon erosion, the detrital sediments including unstable minerals, such as feldspars, and silicate weathering products, carry the signature of the climatedependent leaching history immediately following regolith formation. Vegetation development during short-term floodplain storage acts as a positive feedback on silicate weathering due to acidification of the soils. Not surprisingly, temperature reconstructions derived from vegetation proxies and cation release (the S-index) show remarkable agreement due to the plant-soil continuum (Sheldon et al., 2002; Passchier et al., 2013).

Applying the CIA and the S-index has advantages over clay mineralogy (Robert and Kennett, 1997; Ehrmann and Mackensen, 1992) in that these proxies are not as prone to recycling of allochtonous or older pre-weathered detritus (Thiry, 2000). The products of glacial erosion and comminution, i.e. glacial rock flour, are found primarily in the silt-sized fraction $(2$ to $63 \mu \mathrm{m})$ with subordinate $(<10 \%)$ contributions to the $<2 \mu \mathrm{m}$ clay-sized fractions (Nesbitt and Young, 1996; Passchier, 2000). In contrast, under warmer more humid conditions, a large proportion of silt-sized unstable minerals in regolith break down to form clay minerals through chemical weathering (Thiry, 2000). The paleoclimate interpretation of clay minerals is typically carried out on the $<2 \mu \mathrm{m}$ grain-size fraction. Interpretations of clay mineral data typically exclude glacial rock flour abundance, and instead focus on the relative abundances of four major clay mineral groups: kaolinite, illite, smectite, and chlorite. The particle size distributions of glacial tills on bedrock exhibit small $<2 \mu \mathrm{m}$ fractions $(<10 \%)$ and large silt $(2$ to $63 \mu \mathrm{m})$ fractions (Passchier, 2000). The recycling of chemically pre-weathered clay-mineral material will skew the composition of the $<2 \mu \mathrm{m}$ clay-sized fractions in glacially sourced sediments (Figure 3).

In contrast, the CIA and the S-index are applied to bulk mudrock ( $<2$ to $2000 \mu \mathrm{m}$ size fraction) and assess the cation preservation in feldspar-rich glacial rock flour along with the production of phyllosilicate weathering products in all grain-size fractions (Figure 3). CIA values for Quaternary diamicts and muds on the East Antarctic continental margin range from 47 to 56 with values from 54 to 56 for Quaternary diamicts in Prydz Bay (Passchier and Krissek, 2008 and this study). In comparison, CIAs of Pleistocene tills collected from the Canadian Shield are generally 52, whereas glacial and varved clays are typically between 60 and 65, well below values for the average shale (Nesbitt and Young, 1982, 1996). Hence, along with sedimentary facies analysis, we interpret CIA values below 65 to indicate a significant glacial rock flour contribution to mudrocks sampled in Prydz Bay drillcores and glaciation of the Prydz Bay hinterland. 


\section{INTEGRATED SEISMO-LITHOSTRATIGRAPHY}

The first order stratigraphic framework for the drillsites is provided by interpretations of multi-channel seismic data (Cooper et al., 1991a; Erohina et al., 2004). The Paleogene sequence of interest in our study (Figure 2) encompasses seismic unit PS.2A (Cooper et al., 1991a,b). This unit is overlain by seismic unit PS.1, which extends from the inner shelf to the shelf break and was found to be of Neogene age (Cooper et al., 1991b). On the R/V N.B. Palmer line collected in 2004, the boundary between PS.1 and PS.2 is at approximately 800 ms TWT near Hole 1166A and $\sim 700$ ms TWT near Hole 742A (Handwerger et al., 2004) and corresponds to depths of $\sim 135$ mbsf in Hole 1166A and $\sim 170$ mbsf in Hole 742A. Near Site 739 on the ODP-119 seismic line, the PS.1-PS.2 boundary is positioned at $\sim 700 \mathrm{~ms}$ and corresponds to a depth of $\sim 170$ mbsf near Site 739 (Cooper et al., 1991a).

The PS.2A to PS.2B unconformity (Figure 2) is interpreted based on seismic data as the pre-glacial to glacial boundary (Cooper et al., 1991b). Based on the synthetic seismograms, this boundary is tied to a surface at $\sim 910$ ms TWT in the Palmer ' 04 seismic line near Site 1166 and is penetrated at 267 mbsf in Hole 1166A. It occurs beyond the penetration depth of Hole 742A (Figure 2; Handwerger et al., 2004). Cretaceous pollen and spores, however, are reported within glacio-tectonized beds at the base of Hole 742A (Truswell, 1991; Hambrey et al., 1991), and interpretations of other seismic lines suggest that the pre-glacial to glacial surface lies about $50 \mathrm{~m}$ below the total depth (TD) of Hole 742A (Erohina et al., 2004).

Based on interpretations of the Palmer '04 line, Erohina et al. (2004) subdivided seismic Unit PS.2A into PS.2A1 and PS.2A2 (Figure 2). The top of Unit PS.2A2 is an irregular and discontinuous unconformity, and this unconformity roughly coincides with a downward change to more consistently higher p-wave velocities at $\sim 195$ mbsf in Hole 1166A in a poorly recovered interval (Shipboard Scientific Party, 2001). Based on the presence of equivalent sedimentary facies, Unit PS.2A2 may be laterally continuous between Sites 1166 and 742, with a thicker section of it drilled in Hole 1166A (195-267 mbsf) and a very thin section in Hole 742A (313-315 msbf). The sediments recovered in these intervals consist of contorted and convoluted brownish grey poorly sorted coarse sandstone with dark grey and black mudstone interbeds (Figure 4 and Supplemental Materials). We observed common wood and plant fragments in these strata.

Seismic Unit PS.2A1 was subdivided into three subunits by Erohina et al. (2004). The lowermost PS.2A1CT is laterally continuous between Sites 1166 and 742 and was drilled between 135 and 195 mbsf in Hole 1166A and between 304 and 313 mbsf in Hole 742A. It consists of a fining upward sequence of muddy sandstones, sandy mudstones with dispersed clasts, interlaminated sandstones and mudstones (rhythmites), and bioturbated claystones with dispersed clasts (Figure 4 and Supplemental Materials). Black coal clasts are common. The middle part of PS.2A1 is preserved at Site 742: Seismic Unit PS.2A1G1 occurs at 229-304 mbsf. This unit consists of fining upward grey silty sandstone to sandy siltstone with dm-scale sand interbeds and dispersed clasts. A reflection marking the boundary between PS.2A1G1 and PS.2A1-G2 coincides with a low-velocity interval in the logs and that interval was not recovered in Hole 742A. Seismic Unit PS.2A1-G2 is penetrated in Hole 742A at 170-216 mbsf and near the base of Hole 739C. It consists of grey, locally carbonate cemented, mudstones with dispersed clasts, overlain by interbedded and interlaminated intervals (rhythmites) that are fining up to mudstones that are devoid of sand and gravel clasts (Figure 4 and Supplemental Materials).

In the seismic profile near Site 739 , we distinguish a change from an aggrading system to one with steep prograding clinoforms that was previously recognized by Cooper et al. (1991b). We label the latter unit PS.2A1-G3 (Figure 2). The boundary between the unit PS.2A1-G3 above and unit PS.2A1-G2 below is poorly constrained in Hole $739 \mathrm{C}$ and most likely coincides with a depth of $\sim 425 \mathrm{mbsf}$ in borehole geophysical logs, marking abrupt shifts in P-wave velocity at the top of a unit with relatively high P-wave velocities (Ollier and Mathis, 1991; Volpi et al., 2009). The strata in Seismic Unit PS.2A1-G3 consist 
primarily of diamictites (Figure 4). Below $\sim 300$ mbsf in Hole 739C, the diamictites are massive and clayrich, whereas above $\sim 300 \mathrm{mbsf}$ the diamictites are silt-rich and clay-poor, display evidence of deformation, and occur interbedded with diatomaceous mudstones (Figure 4 and Supplemental Materials). We also recognized a lithologically distinct interval of brownish-grey diamictites with mud ripup clasts at 319-349 mbsf in Hole 739C.

\section{AGE MODELS}

The chronological framework for ODP Sites 739,742 and 1166 (Figures 4 and 5 ) is based on previously published diatom, calcareous nannofossil, and dinoflagellate biostratigraphy, seismostratigraphy, and limited magnetostratigraphy (Sakai and Keating, 1991; Truswell, 1991; Wei and Thierstein, 1991; Florindo et al., 2003; Erohina et al., 2004; Macphail and Truswell, 2004; Warnaar, 2006; Houben et al., 2013). We have converted all ages to the GTS2012 geologic timescale (Vandenberghe et al., 2012).

\section{ODP Hole 739C}

The first common occurrence of the calcareous nannofossil Reticulofenestra daviesii in Core 739C-38R at $\sim 300$ mbsf (Wei and Thierstein, 1991) likely correlates with the onset of an early Oligocene acme documented for this species, which has been dated to 33.7 Ma (Persico et al., 2012). At nearby Site 744, the onset of this acme is calibrated to the base of subchron $\mathrm{C} 13 \mathrm{n}$ in the earliest Oligocene $(\sim 33.7 \mathrm{Ma})$ (Fioroni et al., 2012). The first occurrence of the dinoflagellate Malvinia escutiana in Core 739C-39R at 310.73 mbsf is correlated to the Oi-1 excursion (Houben et al., 2011). These datums constrain the age for the upper $310 \mathrm{~m}$ of strata drilled in Hole $739 \mathrm{C}$ to early Oligocene and younger. A late Eocene dinoflagellate assemblage, which includes Deflandrea sp. A sensu Brinkhuis et al. (2003) and Vozzhennikovia sp., is present from the base of the section up to Core 739C-41R ( 330 mbsf) (Truswell, 1991, Houben et al., 2013). At ODP Site 1172 on the East Tasman Plateau Vozzhennikovia sp. has a last occurrence in Chron C13r (Brinkhuis et al., 2003).

\section{ODP Hole 742A}

During ODP Leg 119, Site 742 was selected for drilling by tracing reflectors correlated to the bottom of Hole 739C landward, where they occur at a shallower depth beneath the seafloor (Barron et al., 1991; Cooper et al., 1991b). Using this strategy, a 130 m interval underlying the section sampled at the base of Hole $739 \mathrm{C}$ was recovered. Hence, a slightly older Eocene interval was drilled in ODP Hole 742A on the inner shelf. The strata recovered from Hole 742A contain rare dinoflagellates (Truswell, 1991) and calcareous nannofossils (Wei and Thierstein, 1991) that confirm a late Eocene age for this section. The magnetic polarity in Hole 742A is almost entirely normal with a few thin reversed polarity intervals (Sakai and Keating, 1991). Three of these reversed polarity intervals coincide with what we observed to be intact carbonate cemented intervals at $\sim 201-205$ and $\sim 280$ mbsf. In the unconsolidated intervals with a gravelly sand component, a normal polarity overprint from drilling is likely, in which case the thin cemented reversed intervals together could point to correlation with either Chron $13 \mathrm{r}$ or $15 \mathrm{r}$.

\section{ODP Hole 1166A}

Site 1166 was drilled to recover sediments from below the stratigraphic level reached at total depth in Hole 742A (Shipboard Scientific Party, 2001). The deeper Eocene succession drilled at ODP Site 1166 was dated to late Eocene based on diatom and dinoflagellate biostratigraphy (Florindo et al., 2003; Warnaar, 2006). Deflandrea sp. A sensu Brinkhuis et al. (2003) is abundant from Core 1166A-17R upward ( 152 mbsf) and is rare below this level down to Core 1166A-26R at 238 mbsf (Warnaar, 2006). This species has a first occurrence (FO) in Chron 16n.1n, which constrains the Eocene interval drilled at these three sites to younger than $35.9 \mathrm{Ma}$. Hole $1166 \mathrm{~A}$ contains a very thin reversed polarity interval at 135.41 to 136.32 mbsf, below an unconformity, with another thicker normal polarity interval below 136.32 
mbsf (Florindo et al., 2003). Based on the absence of the diatom Rhizosolenia oligocaenica (FO 33.8 $\mathrm{Ma}$ ), the interval of normal polarity between 136.32 and $148.0 \mathrm{mbsf}$ was correlated to Chron C15n or older by Florindo et al. (2003). Late Eocene pollen assemblages are in agreement with this interpretation (Macphail and Truswell, 2004). The presence of Deflandrea sp. A. in Hole 1166A (Warnaar, 2006) with first occurrence in chron $\mathrm{C} 16 \mathrm{n} .1 \mathrm{n}$ indicates that the normal polarity strata drilled at Site 1166 correlate to either chron C15n or C16n.1n.

Strata below a sequence boundary at $304 \mathrm{mbsf}$ in Hole 742A can be correlated to Hole 1166A, over a distance of $\sim 40 \mathrm{~km}$, using seismic stratigraphy (Erohina et al., 2004). Considering the superposition of strata in seismic stratigraphy combined with the paleomagnetic and biostratigraphic evidence, we attribute the interval recovered in Hole $742 \mathrm{~A}$ to $\mathrm{C} 13 \mathrm{r}$ or older (considering a normal polarity overprint from drilling), the truncated reversed polarity interval between 135.41 and $136.32 \mathrm{mbsf}$ in Hole $1166 \mathrm{~A}$ to $\mathrm{C} 15 \mathrm{r}$, and the underlying normal polarity interval to C16n.1n (Figures 4 and 5).

\section{RESULTS AND DISCUSSION}

\section{The EOT-1 glaciation}

The first step in the EOT benthic foraminiferal oxygen isotope shift is considered to have been primarily due to deep-water cooling (Katz et al., 2008; Miller et al., 2009; Wade et al., 2012). Some far-field records, however, show step-wise sea level drops starting pre-EOT at $34.4 \mathrm{Ma}$ (Miller et al., 2008; p. 51). The combined sedimentological and geochemical evidence from ODP Site 739 points to an onset of largescale glaciation of the Princess Elizabeth and Mac. Robertson Land margins of Antarctica during the EOT-1 "precursor" glaciation. Specifically, the latest Eocene CIA excursion at Site 739 to a "glacial" value of 61 occurred for the first time at $\sim 34.2 \mathrm{Ma}$, which is in excellent agreement with the age of the EOT-1 increase in benthic $\delta^{18} \mathrm{O}$. This decline in CIA above $425 \mathrm{mbsf}$ in Hole $739 \mathrm{C}$ is accompanied by the onset of deposition of sandy diamictite (Figure 6) on the outer shelf of Prydz Bay and marks a shift in seismic stratigraphic signature from aggrading to prograding clinoforms at the base of unit PS.2A1-G3 (Figure 2). Furthermore, Apatite Fission Track (APT) ages in Hole 739C mark a change in the erosion history of the Prydz Bay hinterland at this time (Tochilin et al., 2012). A decrease in lag time from $\sim 250$ Myr to $\sim 210$ Myr between 386 and 330 mbsf (34.2-33.8 Ma) in Hole 739C indicates the onset of enhanced erosion and delivery of that material to Site 739 on the outer shelf of Prydz Bay (Figure 7). The enhanced erosion likely resulted from the development of valley glaciers expanding outward from wet-based ice caps with glacial overdeepening, followed by the establishment of permanent cold ice at high elevation (Rose et al., 2013). The precursor (EOT-1) is also recognized as a fish-teeth $\mathrm{Nd}$ isotope step dated $\sim 34.2 \mathrm{Ma}$ at Site 738 on the southern Kerguelen Plateau in the vicinity of Prydz Bay (Figure 8). The Nd isotope excursions at this site are interpreted as increases in the delivery of dissolved non-radiogenic $\mathrm{Nd}$ to the circumpolar water masses that originated from an enhanced East Antarctic glacial erosional flux (Scher et al., 2011).

In contrast to ice-sheet reconstructions in the Ross Sea (Galeotti et al., 2016), evidence of glaciomarine sedimentation and ice-influenced mass-gravity flows mark the arrival of an ice sheet grounding line onto the Prydz Bay continental shelf prior to the Oi-1 (Figure 7). A lithologically distinct interval of brownishgrey diamictites with mud rip-up clasts between 349 and 319 mbsf (33.9-33.7 Ma) in Hole 739C resembles sediments recovered in a more recent glaciogenic trough mouth fan drilled farther offshore (Passchier et al., 2003). The Lambert Graben was above sea level at Eocene-Oligocene boundary times (Figure 1; Wilson et al., 2012). Furthermore, in the ice-sheet model with dynamic topography of Stocchi et al. (2013) the first phase of continental scale glaciation to an ice sheet size about $55 \%$ of the modern is marked by a rapid relative sea level (RSL) fall at Site 739 due to the lateral expansion of the forebulge (using a lithospheric thickness of $175 \mathrm{~km}$ for Prydz Bay). This allowed the grounding line to advance much closer to the drillsites than would be possible at present-day depth. Conversion of the S-index for the Prydz Bay cores documents a long-term temperature decline of $>3^{\circ} \mathrm{C}$ between $34.4 \mathrm{Ma}$ and the Oi-1 
(Figure 8). Consistent with this interpretation, Subantarctic sea surface temperatures began to decline at $\sim 34.5 \mathrm{Ma}$ (Plancq et al., 2014), reaching a minimum $\sim 33.6 \mathrm{Ma}$ (Liu et al., 2009) when ice sheets reached the outer continental shelf of Prydz Bay.

The Oi-1 time (33.7-33.5 Ma) was characterized by maximum glacial conditions in Prydz Bay. We follow earlier interpretations of the silt-rich and clay-poor diamict lithofacies above $\sim 300 \mathrm{mbsf}(\sim 33.6 \mathrm{Ma})$ at Site 739C (Figure 4) and infer that these are ice-proximal sediments (Hambrey et al., 1991) deposited by a marine ice sheet that was grounded on the shelf near, but not over, Site 739 during glacial periods. The strongly cyclic deposition in Prydz Bay following the Oi-1 is consistent with orbitally paced ice advance and retreat by a dynamic early Oligocene ice sheet (Coxall et al., 2005; Pälike et al., 2006; Coxall and Wilson, 2011). The development of a large ice sheet is associated with a decline in CIA values of diamicts within Hole $739 \mathrm{C}$. At $33.5 \mathrm{Ma}(260 \mathrm{mbsf})$, CIAs reach the lowest value of 57 , near the upper limit for Quaternary diamicts (54-56) in Prydz Bay (Figures 6 and 8). In agreement with our record, the largest $\mathrm{Nd}$ isotope excursion at Site 738 (Kerguelen Plateau) occurs at the onset of the Oi-1 isotope shift at 33.7 $\mathrm{Ma}$, along with the arrival of ice-rafted debris (Scher et al., 2011).

\section{Late Eocene high latitude climate variability prior to the EOT}

Mountain glaciation of the Prydz Bay hinterland began prior to the EOT. Glacial microtextures are present on sand grains within seismic unit PS.2A2 down to Core 1166A-26R (Strand et al., 2003) at 240 mbsf and date the onset of glaciation to $\sim 35.9 \mathrm{Ma}$. Apatite fission track ages along with (U-Th)/He cooling ages of sediments recovered between $\sim 140$ and $240 \mathrm{mbsf}$ in Hole 1166A, however, reveal that erosion rates in the hinterland were low (Cox et al., 2010; Thomson et al., 2013) at 35.9-35.7 Ma. The provenance of the sand fraction of these sediments points to a source in Pan-African terrains to the east or south of Prydz Bay and lacks material derived from the western rift flank of the Lambert Graben (van de Flierdt et al., 2008; Thomson et al., 2013). Furthermore, CIAs show large fluctuations with values ranging between $\sim 67$ and 80 (Figures 5 and 8). The lower end of this range (67) would allow for some limited physical weathering and glaciation. CIAs were still however well above the range measured for Quaternary diamicts from Prydz Bay ( $\mathrm{CIA}=54-56)$ with insignificant illite and chlorite in the clay mineral assemblages (Figure 4; Hambrey et al., 1991; Shipboard Scientific Party, 2001; Forsberg et al., 2008).

In contrast to the permanent ice sheet that was established during the Eocene-Oligocene transition precursor glaciation, the combined evidence from Holes 742A and 1166A points to ephemeral, partial, glaciation prior to EOT time. An appropriate modern analogue for the late Eocene pre-EOT depositional system in Prydz Bay could be Malaspina glacier in Alaska, a temperate piedmont glacier that extends from a nearby mountain range into the partially vegetated coastal plain (Gustavson and Boothroyd, 1987). Seismic unit PS.2A2 has chaotic internal and upper reflections and is overlain by Units PS.2A1-CT, PS.2A1-G1, and PS.2A1-G2 which downlap and drape onto an irregular reflection surface at $\sim 195$ mbsf in 1166 (Figure 2). In Holes 1166A and 742A these PS.2A1 sequences are characterized upward by successions of glaciotectonized coastal plain sediments, rhythmites, and bioturbated mudstones (this study and Hambrey et al., 1991), facies that are consistent with an Alaska-type piedmont glacier system (Gustavson and Boothroyd, 1987). The lack of diamictite and a fluvial imprint on the sediment with rounded gravel and coarse sand in the pre-EOT interval of Hole 1166A are consistent with descriptions of other mountain glacial systems driven by high snow accumulation (New Zealand; Hambrey and Ehrmann, 2004).

The reconstructed paleogeography of Princess Elizabeth Land during the Eocene to Oligocene interval (Wilson et al., 2012; Figure 1) suggests the presence of higher elevation (>1000 m) terrain at $70-75^{\circ} \mathrm{S}$ directly south of the Prydz Bay drillsites (within $\sim 200 \mathrm{~km}$ of the paleoshoreline). Based on the S-index values determined for the upper Eocene intervals of Holes $742 \mathrm{~A}$ and $739 \mathrm{C}$, mean annual temperatures in the coastal region during this time were generally $10 \pm 3.6^{\circ} \mathrm{C}$ (Figure 8). As discussed in Passchier et al. (2013), Antarctic MAT values based on the S-index could represent mean summer temperatures due 
to the strong seasonality of the high-latitude climate. Precipitation rates exceeding $1200 \mathrm{~mm} / \mathrm{yr}$ are suggested based on palynomorph evidence for a late Eocene rainforest shrub vegetation in the hinterland of the drillsites (Macphail and Truswell, 2004). The humid conditions likely supported the development of accumulation-driven temperate glacial systems in the coastal sections of Princess Elizabeth Land prior to the EOT.

\section{Late Eocene high-latitude warming events}

Bioturbated and massive clayey siltstones within the upper Eocene sequences in Holes 742A and 1166A exhibit CIA maxima near 80 . CIAs that high require severe chemical weathering in the source regions of the sediments (Nesbitt and Young, 1982). Using a temperature climofunction based on the S-index (Sheldon et al., 2002; Passchier et al., 2013) and following our age model, the maxima are dated at 235.8 and $34.8 \mathrm{Ma}$ and represent mean annual temperature excursions of $3^{\circ} \mathrm{C}$, each lasting $<100 \mathrm{kyr}$ (Figure 8). Similar short-lived transient warm events within the interval of ephemeral glaciation had previously been recognized in the Southern Ocean, where they occur superimposed onto an Eocene cooling trend (Bohaty and Zachos, 2003). Compared to global transient $(<100 \mathrm{kyr})$ warming events that occurred frequently in the early and early middle Eocene (Sexton et al., 2011), the late Eocene events observed in the Prydz Bay records may be of similar duration.

A $\sim 0.5 \%$ decrease in benthic and bulk carbonate $\delta^{13} \mathrm{C}$ was found at South Atlantic ODP Sites 689 and 1090 , where it is stratigraphically correlated with a $\sim 35.8$ Ma clinopyroxene spherule layer and Ir spike attributed to the Popigai impact structure (Vonhof et al., 2000; Pusz et al., 2009). Using this well-dated Ir-spike as a stratigraphic marker, it can be demonstrated that the carbon isotope excursion is not diachronous and represents a global event. Within age model uncertainties, the carbon isotope excursion overlaps with the high-latitude warming we document in the upper Eocene strata of Prydz Bay, and it is also expressed as an oxygen isotope step at ODP Site 689 (Vonhof et al., 2000) (Figure 8). Records of bulk carbonate $\delta^{18} \mathrm{O}$ also suggest $2.5^{\circ} \mathrm{C}$ of surface warming in the South Atlantic at Site 1090 at $\sim 35.8$ Ma (Pusz et al., 2009). Although the timing of the warming at $\sim 34.8 \mathrm{Ma}$ is somewhat uncertain due to age model limitations for Hole $742 \mathrm{~A}$ (Figure 5 ), the $\sim 35.8 \mathrm{Ma}$ event is better constrained by the age model for Hole 1166A.

The 35.8 Ma high-latitude warm event correlates well with a sea level record from Saint Stevens Quarry, Alabama that documents a highstand within Chron 16n.1n at 35.9-35.7 Ma (Miller et al., 2008). Additionally, at Wadi al-Hitan in Egypt, Peters et al. (2010) documented sea level fluctuations of $\sim 40 \mathrm{~m}$ from a valley fill dated to within nannofossil zone NP19/20 ( 37-35 Ma). Finally, backstripping of stratigraphy drilled in the United States mid-Atlantic coastal plain (Kominz et al., 2008) produces consistent sea level signals in seven drillholes with several sea level high stands in excess of $50 \mathrm{~m}$ above present at $\sim 36-35 \mathrm{Ma}$ (sequence E10). The magnitude of change in these sea level reconstructions, equivalent to about $50 \%$ of modern East Antarctic Ice Sheet volume, however, contrasts with the limited extent of pre-EOT mountain glaciation that we reconstruct in the Prydz Bay hinterland, although we cannot rule out ice growth elsewhere in Antarctica.

\section{Uncertainties of weathering proxies}

The CIAs and estimated MATs from the Prydz Bay sediments are likely to be only slightly elevated due to the recycling of weathered material. CIA values of Quaternary diamicts in Hole $739 \mathrm{C}$ that originated without chemical weathering are 54-56, elevated about 8-10 units above the value of 46 for average upper crust (Nesbitt and Young, 1982; 1996). At the same time, between $\sim 30$ and $60 \%$ of smectite+kaolinite is present in the $<2 \mu \mathrm{m}$ fractions of EOT diamictites in Hole $739 \mathrm{C}$ (Hambrey et al., 1991; Ehrmann et al., 1992) that have "glacial" CIA values < 62. Notably, in ice-proximal sediments the $<2 \mu \mathrm{m}$ fine fraction is only a very small proportion of the bulk sediment and it is easily swamped by contributions of clay material recycled via glacial erosion from pre-glacial chemically weathered sediment 
sources (Figures 3). The CIA and S-index, however, also reflect feldspar preservation in the silt and sand fraction $(2-2000 \mu \mathrm{m})$ and account for the presence or absence of products of glacial comminution that are not abundant in $<2 \mu \mathrm{m}$ fraction (Figure 3). In the EOT interval of Hole $739 \mathrm{C}$, the $<2 \mu \mathrm{m}$ fraction makes up only $10-20 \%$ of the bulk sediment in the particle size distributions. This means that both $\mathrm{CIAs}$ and MATs in the Eocene-Oligocene intervals of the Prydz Bay cores compare to only slightly lower (more glacial) values to account for the recycling of weathered materials that do not affect the interpretations.

The upper Eocene CIA and MAT maxima (warm events) in Holes 1166A and 742A are accompanied by high smectite and kaolinite contents, which make up more than $80 \%$ of the $<2 \mu \mathrm{m}$ fraction (Hambrey et al., 1991; Forsberg et al., 2008; Figure 4). Previously, the kaolinite in Prydz Bay cores had been attributed to erosion and recycling of Permian sedimentary rocks from within the Lambert Graben and its rift flank (Ehrmann et al., 1992). The $<2 \mu \mathrm{m}$ fraction that contains these clay minerals, however, makes up $<20 \%$ of the bulk sediment for the core intervals in question. The silt and sand provenance of the upper Eocene of Hole 1166A points to Pan-African and older sources and the data does not support a major contribution from Permian or younger rocks (van de Flierdt et al., 2008; Cox et al., 2010). Further, recycling of isolated chemically weathered sedimentary sources rich in smectite and kaolinite would require very localized precipitation and runoff. In the late Eocene, fine-grained hemipelagic sediments likely originated by gravity settling from sediment plumes entering the marine basin from point sources, such as streams (Wilson et al., 2012). To achieve CIAs as high as 80 by source switching alone (in the absence of chemical weathering) one would need to invoke sediment delivery exclusively from isolated weathered source terrains without input of suspended mud from mechanically weathered sources along the basin margin, which would lower the CIA. Thus, while it is possible that some of the clay minerals are recycled, it is not likely that CIAs represent bulk sediment exclusively derived from physical erosion of preweathered sediment. A more plausible explanation is that these CIA excursions represent warm episodes with an active hydrological cycle and the delivery of chemically weathered fine-grained sediment via runoff from a variety of exposed source terrains.

\section{Antarctic warm events, ice growth and the global carbon cycle}

The onset of continent-wide Antarctic glaciation at the EOT was preceded by a long-lived global cooling trend that started in the Early Eocene $\sim 50 \mathrm{Ma}$ and is recognized at high southern latitudes in fossil terrestrial floras (Francis et al., 2008; Pross et al., 2012), marine faunas (Ivany et al., 2008; Bijl et al., 2013), and sea surface temperatures (Hollis et al., 2009; Bijl et al., 2009; 2013; Douglas et al., 2014). Superimposed transient Eocene warming events are generally attributed to releases of atmospheric greenhouse gases from tectonic, metamorphic, ocean ventilation, methane hydrate (Dickens, 2003), or permafrost (DeConto et al., 2012) sources. Marine and terrestrial proxies show declining concentrations of atmospheric $\mathrm{pCO}_{2}$ through the mid-to-late Eocene (Beerling and Royer, 2011; Pearson et al., 2009; Pagani et al., 2011; Anagnostou et al., 2016; Steinthorsdottir et al., 2016), but short-term fluctuations are not yet well represented due to the low temporal resolution of the records.

Reduced radiative forcing by greenhouse gases was likely the primary driver for the long-term high latitude cooling that preceded ice growth (Anagnostou et al., 2016). Long-term $\mathrm{CO}_{2}$ decline likely provided the required underlying preconditioning for the EOT (DeConto and Pollard, 2003) and cool summers due to the coincidence of an eccentricity minimum and low amplitude obliquity at $\sim 34$ Ma provided a tipping point for sustained major Antarctic glaciation (Coxall et al., 2005). We conclude from the Prydz Bay record that in East Antarctica an EOT-1 ice sheet formed during a time of declining $\mathrm{pCO}_{2}$ (Pagani et al., 2011; Pearson et al., 2009; Steinthorsdottir et al., 2016). The onset of diamict deposition, the prograding clinoforms in seismic data, the declining values of the CIA, and enhanced erosion and glacial weathering rates (Scher et al., 2011; Tochilin et al., 2012) all suggest that high-latitude climate deterioration and ice growth in the hinterland of Prydz Bay intensified 0.5 Myr prior to Oi-1 with major ice growth coincident with Eocene-Oligocene precursor glaciaton (Figure 8). 
The mechanism for the Eocene atmospheric greenhouse decrease is not known and may have involved the ice sheet itself as a climate feedback (Zachos and Kump, 2005; Merico et al., 2008; Miller et al., 2009). Carbon sinks involving the production of fine-grained reactive detrital material by expanding temperate ice sheets, such as enhanced silicate weathering and fertilization of primary productivity (Zachos et al., 1999; Zachos and Kump, 2005; Scher et al., 2011) may have operated. The deepening of the Tasmanian Gateway between 35.5 and 30 Ma (Stickley et al., 2004) may have initiated regional climate deterioration (Sijp et al., 2011). Additionally, the albedo effect of a large Antarctic ice sheet and the initiation of katabatic winds (DeConto et al., 2007) may have increased latitudinal thermal gradients resulting in sea ice formation (Houben et al., 2013), more vigorous ocean circulation and increased nutrient supply through upwelling, allowing for further increases in primary productivity and carbon drawdown (Miller et al., 2009). The efficacy of this mechanism is called into question, however, based on the results of biogeochemical box model experiments (Merico et al., 2008; Armstrong-McKay et al., 2016). The role of gateway opening is also questioned as modeling suggests that the circumpolar flow was limited due to the continuous obstruction of the Australian landmass (Sijp et al., 2011; Hill et al., 2013). The degree to which Drake Passage was open is not well constrained. Modeling experiments favor weathering of carbonate platforms and deep-sea burial during glacio-eustatic sea level fall (Merico et al., 2008), ocean ventilation, and expansion of terrestrial carbon storage in permafrost and peatland reservoirs (Armstrong-McKay et al., 2016).

Establishment of a stable Antarctic Ice Sheet grounded within the Ross Embayment was recently suggested to have occurred at 32.8 Ma (Galeotti et al., 2016). Solid earth feedbacks in response to ice growth however affected ice-sheet ocean interactions in the late Eocene and early Oligocene. In the model of Stocchi et al., (2013), relative sea level stayed high in the Ross Sea through the onset of ice growth and decreased in Prydz Bay potentially allowing the ice sheet to advance earlier. Our record with ice on the continental shelf prior to $33.7 \mathrm{Ma}$ lends credence to the results of a modeling study with more realistic insolation forcing than previous models that showed ice growth under higher $\mathrm{pCO}_{2}$ and a stepwise pattern of ice growth (Ladant et al., 2014). The spatial and temporal evolution of ice growth and surface temperature is still too poorly known from high-latitude stratigraphic records to confidently assess relationships between ice volume, high-latitude SST, and atmospheric $\mathrm{CO}_{2}$. Hence, to advance our understanding of the late Eocene cooling and its global effects, we recommend additional modeling, proxy data collection and new drilling at high latitude, ice-proximal sites.

\section{CONCLUSIONS}

Our geochemical weathering data provide the first well-resolved near-field record of Antarctic continental ice growth, temperature and weathering changes during the Eocene-Oligocene transition on the East Antarctic margin. These data confirm the presence of ephemeral mountain glaciers on East Antarctica during the late Eocene between 35.9 and $34.4 \mathrm{Ma}$. High latitude warming events are recognized at $\sim 35.8$ and $34.8 \mathrm{Ma}$. Furthermore, we document the stepwise climate cooling of the Antarctic hinterland from 34.4 $\mathrm{Ma}$ as the ice sheet advanced towards the edges of the continent during during the EoceneOligocene precursor interval. The youngest part of our data set correlates to the time interval of the Oi-1 glaciation, when the ice-sheet in Prydz Bay extended to the outer shelf. Cooling and ice growth on Antarctica were spatially variable and ice sheets formed under declining $\mathrm{pCO}_{2}$. These results pose a challenge to some ice sheet and Earth system models and point to ice sheet - atmosphere - ocean solid-earth feedbacks that are currently poorly represented in the models. Thus, future efforts should be directed to new proxy data collection and drilling at high latitude sites to allow data-model comparison at appropriate spatial and temporal resolution.

\section{ACKNOWLEDGMENTS}


This research used samples provided by the International Ocean Discovery Program. Funding for this research came from the U.S. National Science Foundation (award \# ANT-1245283) to S. Passchier. P.K. Bijl thanks NWO-VENI for grant no 863.13.002. This research also benefited from a Global Education Grant from Montclair State University. Dr. Phil Rumford and his staff are thanked for assistance during work at the Gulf Coast Core Repository in College Station, TX. Nick Tadrick is thanked for carrying out some of the sample preparations, and Dr. Xiaona Li for assistance with the ICP-OES measurements at Montclair State University. Constructive feedback from Paul Wilson and an anonymous reviewer significantly improved the manuscript.

\section{REFERENCES CITED}

Anagnostou, E., John, E.H., Edgar, K.M., Foster, G.L., Ridgwell, A., Inglis, G.N., Pancost, R.D., Lunt, D.J. and Pearson, P.N., 2016. Changing atmospheric $\mathrm{CO}_{2}$ concentration was the primary driver of early Cenozoic climate: Nature, v. 533, no. 7603 , p. 380-384.

Armstrong McKay, D. I., Tyrrell, T., and Wilson, P. A., 2016, Global carbon cycle perturbation across the Eocene-Oligocene climate transition: Paleoceanography, v. 31, no. 2, p. 311-329.

Barron, J., Larsen, B., et al., 1989. Proceedings of the Ocean Drilling Program, Initial Reports, volume 119, U.S. Government Printing Office, College Station, Texas.

Barron, J., Larsen, B., and Baldauf, J. G., 1991, Evidence for Late Eocene to Early Oligocene Antarctic Glaciation and Observations on Late Neogene Glacial History of Antarctica: Results from Leg 119, Proceedings of the Ocean Drilling Program, volume 119. U.S. Government Printing Office, College Station, Texas.

Beerling, D. J., and Royer, D. L., 2011, Convergent Cenozoic $\mathrm{CO}_{2}$ history: Nature Geoscience, v. 4, no. 7, p. 418-420.

Bijl, P. K., Bendle, J. A., Bohaty, S. M., Pross, J., Schouten, S., Tauxe, L., Stickley, C. E., McKay, R. M., Röhl, U., Olney, M., Sluijs, A., Escutia, C., Brinkhuis, H., and Expedition, S., 2013, Eocene cooling linked to early flow across the Tasmanian Gateway: Proc. Natl. Acad. Sci. U.S.A., v. 110, no. 24, p. 9645-9650.

Bijl, P. K., Schouten, S., Sluijs, A., Reichart, G. J., Zachos, J. C., and Brinkhuis, H., 2009, Early Palaeogene temperature evolution of the southwest Pacific Ocean: Nature, v. 461, no. 7265, p. 776779 .

Bo, S., Siegert, M.J., Mudd, S.M., Sugden, D., Fujita, S., Xiangbin, C., Yunyun, J., Xueyuan, T. and Yuansheng, L., 2009, The Gamburtsev mountains and the origin and early evolution of the Antarctic Ice Sheet: Nature, v. 459, no. 7247, p.690-693.

Bohaty, S. M., and Zachos, J. C., 2003, Significant Southern Ocean warming event in the late middle Eocene: Geology, v. 31, no. 11, p. 1017-1020.

Bohaty, S. M., Zachos, J. C., and Delaney, M. L., 2012, Foraminiferal Mg/Ca evidence for Southern Ocean cooling across the Eocene-Oligocene transition: Earth and Planetary Science Letters, v. 317318 , p. 251-261.

Brinkhuis, H., Sengers, S., Sluijs, A., Warnaar, J., Williams, G.L., 2003a. Latest Cretaceous to earliest Oligocene, and Quaternary dinoflagellates from ODP Site 1172, East Tasman Plateau, in: Exon, N., Kennett, J. P. (Eds.), Proceedings of the Ocean Drilling Program, Scientific Results, volume 189. U.S. Government Printing Office, College Station, Texas. 
Ciarletta, D.J., 2014. Characterization of Eocene-Oligocene depocenters in Prydz Bay, East Antarctica: A lithostratigraphic correlation of ODP Sites 739, 742, and 1166. [M.S. Thesis], Montclair State University, 61p.

Cooper, A., Stagg, H., and Geist, E., 1991a, Seismic Stratigraphy and Structure of Prydz Bay, Antarctica: Implications from Leg 119 Drilling, Proceedings of the Ocean Drilling Program, Scientific Results, volume 119, U.S. Government Printing Office, College Station, Texas.

Cooper, A. K., Barrett, P. J., Hinz, K., Traube, V., Letichenkov, G., and Stagg, H. M. J., 1991b, Cenozoic prograding sequences of the Antarctic continental margin: a record of glacio-eustatic and tectonic events: Marine Geology, v. 102, no. 1-4, p. 175-213.

Cox, S. E., Thomson, S. N., Reiners, P. W., Hemming, S. R., and van de Flierdt, T., 2010, Extremely low long-term erosion rates around the Gamburtsev Mountains in interior East Antarctica: Geophysical Research Letters, v. 37, no. 22, p. n/a-n/a.

Coxall, H. K., Wilson, P. A., Palike, H., Lear, C. H., and Backman, J., 2005, Rapid stepwise onset of Antarctic glaciation and deeper calcite compensation in the Pacific Ocean: Nature, v. 433, no. 7021, p. 53-57.

Coxall, H. K, Wilson, P. A, 2011, Early Oligocene glaciation and productivity in the eastern equatorial Pacific: Insights into global carbon cycling: Paleoceanography, v. 26, no. 2., p. n/a-n/a.

DeConto, R.M. and Pollard, D., 2003, Rapid Cenozoic glaciation of Antarctica induced by declining atmospheric $\mathrm{CO}_{2}$ : Nature, v. 421 , no. 6920 , p. 245-249.

DeConto, R. M., Pollard, D. and Harwood, D., 2007, Sea ice feedback and Cenozoic evolution of Antarctic climate and ice sheets: Paleoceanography, v. 22, PA3214.

DeConto, R. M., Galeotti, S., Pagani, M., Tracy, D., Schaefer, K., Zhang, T., Pollard, D., and Beerling, D. J., 2012, Past extreme warming events linked to massive carbon release from thawing permafrost: Nature, v. 484, no. 7392 , p. 87-91.

Dickens, G. R., 2003, Rethinking the global carbon cycle with a large, dynamic and microbially mediated gas hydrate capacitor: Earth and Planetary Science Letters, v. 213, no. 3-4, p. 169-183.

Diester-Haass, L., and Zahn, R., 1996, Eocene-Oligocene transition in the Southern Ocean: History of water mass circulation and biological productivity: Geology, v. 24, no. 2, p. 163-166.

Douglas, P. M., Affek, H. P., Ivany, L. C., Houben, A. J., Sijp, W. P., Sluijs, A., Schouten, S., and Pagani, M., 2014, Pronounced zonal heterogeneity in Eocene southern high-latitude sea surface temperatures: Proc. Natl. Acad. Sci. U. S. A., v. 111, no. 18, p. 6582-6587.

Egli, M., Fitze, P. and Mirabella, A., 2001, Weathering and evolution of soils formed on granitic, glacial deposits: results from chronosequences of Swiss alpine environments: Catena, v. 45, p. 19-47.

Ehrmann, W. U., and Mackensen, A., 1992, Sedimentological evidence for the formation of an East Antarctic ice sheet in Eocene/Oligocene time: Palaeogeography, Palaeoclimatology, Palaeoecology, v. 93, no. 1-2, p. 85-112.

Ehrmann, W.U., Melles, M., Kuhn, G. and Grobe, H., 1992, Significance of clay mineral assemblages in the Antarctic Ocean: Marine Geology, v. 107, no. 4, p.249-273. 
Erohina, T., Cooper, A., Handwerger, D., and Dunbar, R., 2004, Seismic Stratigraphic Correlations between ODP Sites 742 and 1166: Implications for Depositional Paleoenvironments in Prydz Bay, Antarctica, in Cooper, A. K., O'Brien, P. E., and Richter, C., eds., Proceedings of the Ocean Drilling Program, Scientific Results, Volume 188: College Station, TX, Ocean Drilling Program.

Fioroni, C., Villa, G., Persico, D., Wise, S. W., and Pea, L., 2012, Revised middle Eocene-upper Oligocene calcareous nannofossil biozonation for the Southern Ocean: Revue de Micropaléontologie, v. 55 , no. 2 , p. 53-70.

Florindo, F., Bohaty, S. M., Erwin, P. S., Richter, C., Roberts, A. P., Whalen, P. A., and Whitehead, J. M., 2003, Magnetobiostratigraphic chronology and palaeoenvironmental history of Cenozoic sequences from ODP sites 1165 and 1166, Prydz Bay, Antarctica: Palaeogeography, Palaeoclimatology, Palaeoecology, v. 198, no. 1-2, p. 69-100.

Forsberg, C. F., Florindo, F., Grützner, J., Venuti, A., and Solheim, A., 2008, Sedimentation and aspects of glacial dynamics from physical properties, mineralogy and magnetic properties at ODP Sites 1166 and 1167, Prydz Bay, Antarctica: Palaeogeography, Palaeoclimatology, Palaeoecology, v. 260, no. 1-2, p. 184-201.

Francis, J. E., Marenssi, S., Levy, R., Hambrey, M., Thorn, V. C., Mohr, B., Brinkhuis, H., Warnaar, J., Zachos, J., Bohaty, S., and DeConto, R., 2008, Chapter 8 From Greenhouse to Icehouse - The Eocene/Oligocene in Antarctica, v. 8, p. 309-368.

Galeotti, S., DeConto, R., Naish, T., Stocchi, P., Florindo, F., Pagani, M., Barrett, P., Bohaty, S. M., Lanci, L., Pollard, D., Sandroni, S., Talarico, F. M., and Zachos, J. C., 2016, Antarctic Ice Sheet variability across the Eocene-Oligocene boundary climate transition: Science, v. 352, no. 6281, p. 7680.

Goldner, A., Herold, N., and Huber, M., 2014, Antarctic glaciation caused ocean circulation changes at the Eocene-Oligocene transition: Nature, v. 511, no. 7511, p. 574-577.

Gustavson, T. C., and Boothroyd, J. C., 1987, A depositional model for outwash, sediment sources, and hydrologic characteristics, Malaspina Glacier, Alaska: A modern analog of the southeastern margin of the Laurentide Ice Sheet: Geological Society of America Bulletin, v. 99, no. 2, p. 187.

Hambrey, M., and Ehrmann, W., 2004, Modification of sediment characteristics during glacial transport in high-alpine catchments: Mount Cook area, New Zealand: Boreas, v. 33, no. 4, p. 300-318.

Hambrey, M. J., Ehrmann, W. U., and Larsen, B., 1991, Cenozoic Glacial Record of the Prydz Bay Continental Shelf, East Antarctica, Proceedings of the Ocean Drilling Program, volume 119. U.S. Government Printing Office, College Station, Texas.

Handwerger, D. A., Cooper, A. K., O'Brien, P. E., Williams, T., Barr, S. R., Dunbar, R. B., Leventer, A., and Jarrard, R. D., 2004, Synthetic Seismograms Linking ODP Sites to Seismic Profiles, Continental Rise and Shelf of Prydz Bay, Antarctica, in Cooper, A. K., O'Brien, P. E., and Richter, C., eds., Proceedings of the Ocean Drilling Program, Scientific Results, Volume 188: College Station, TX, Ocean Drilling Program.

Hill, D. J., Haywood, A. M., Valdes, P. J., Francis, J. E., Lunt, D. J., Wade, B. S., and Bowman, V. C., 2013, Paleogeographic controls on the onset of the Antarctic circumpolar current: Geophysical Research Letters, v. 40, no. 19 , p. 5199-5204. 
Hollis, C. J., Handley, L., Crouch, E. M., Morgans, H. E. G., Baker, J. A., Creech, J., Collins, K. S., Gibbs, S. J., Huber, M., Schouten, S., Zachos, J. C., and Pancost, R. D., 2009, Tropical sea temperatures in the high-latitude South Pacific during the Eocene: Geology, v. 37, no. 2, p. 99-102.

Houben, A. J. P., Bijl, P. K., Guerstein, G. R., Sluijs, A., and Brinkhuis, H., 2011, Malvinia escutiana, a new biostratigraphically important Oligocene dinoflagellate cyst from the Southern Ocean: Review of Palaeobotany and Palynology, v. 165, no. 3-4, p. 175-182.

Houben, A. J., Bijl, P. K., Pross, J., Bohaty, S. M., Passchier, S., Stickley, C. E., Rohl, U., Sugisaki, S., Tauxe, L., van de Flierdt, T., Olney, M., Sangiorgi, F., Sluijs, A., Escutia, C., Brinkhuis, H., Expedition, S., Dotti, C. E., Klaus, A., Fehr, A., Williams, T., Bendle, J. A., Carr, S. A., Dunbar, R. B., Flores, J. A., Gonzalez, J. J., Hayden, T. G., Iwai, M., Jimenez-Espejo, F. J., Katsuki, K., Kong, G. S., McKay, R. M., Nakai, M., Pekar, S. F., Riesselman, C., Sakai, T., Salzmann, U., Shrivastava, P. K., Tuo, S., Welsh, K., and Yamane, M., 2013, Reorganization of Southern Ocean plankton ecosystem at the onset of Antarctic glaciation: Science, v. 340, no. 6130 , p. 341-344.

Ivany, L. C., Lohmann, K. C., Hasiuk, F., Blake, D. B., Glass, A., Aronson, R. B., and Moody, R. M., 2008, Eocene climate record of a high southern latitude continental shelf: Seymour Island, Antarctica: Geological Society of America Bulletin, v. 120, no. 5-6, p. 659-678.

Katz, M. E., Miller, K. G., Wright, J. D., Wade, B. S., Browning, J. V., Cramer, B. S., and Rosenthal, Y., 2008, Stepwise transition from the Eocene greenhouse to the Oligocene icehouse: Nature Geoscience, v. 1 , no. 5 , p. 329-334.

Kennett, 1978, Cainozoic evolution of circum-Antarctic paleoceanography, in: van Zinderen Bakker, E., Antarctic Glacial History and World Paleoenvironments: A.A. Balkema, Rotterdam, p. 41-56.

Kominz, M. A., Browning, J. V., Miller, K. G., Sugarman, P. J., Mizintseva, S., and Scotese, C. R., 2008, Late Cretaceous to Miocene sea-level estimates from the New Jersey and Delaware coastal plain coreholes: an error analysis: Basin Research, v. 20, no. 2, p. 211-226.

Ladant, J.-B., Donnadieu, Y., Lefebvre, V., and Dumas, C., 2014, The respective role of atmospheric carbon dioxide and orbital parameters on ice sheet evolution at the Eocene-Oligocene transition: Paleoceanography, v. 29, p. 810-823.

Lear, C. H., Bailey, T. R., Pearson, P. N., Coxall, H. K., and Rosenthal, Y., 2008, Cooling and ice growth across the Eocene-Oligocene transition: Geology, v. 36, no. 3, p. 251.

Liu, Z., Pagani, M., Zinniker, D., Deconto, R., Huber, M., Brinkhuis, H., Shah, S. R., Leckie, R. M., and Pearson, A., 2009, Global cooling during the Eocene-Oligocene climate transition: Science, v. 323, no. 5918, p. 1187-1190.

Macphail, M. K., and Truswell, E. M., 2004, Palynology of Site 1166, Prydz Bay, East Antarctica, in Cooper, A. K., O'Brien, P. E., and Richter, C., eds., Proceedings of the Ocean Drilling Program, Scientific Results, Volume 188: College Station, TX, Ocean Drilling Program.

Mazullo, J., and Graham, A. G., 1988, Handbook for Shipboard Sedimentologists: Texas A\&M University.

Merico, A., Tyrrell, T. and Wilson, P.A., 2008, Eocene/Oligocene ocean de-acidification linked to Antarctic glaciation by sea-level fall: Nature, v. 452, no. 7190, p. 979-982. 
Miller, K. G., Wright, J. D., Katz, M. E., Wade, B., Browning, J. V., Cramer, B. S., and Rosenthal, Y., 2009, Climate threshold at the Eocene-Oligocene transition: Antarctic ice sheet influence on ocean circulation, in Koeberl, C., and Montanari, A., ed., The late Eocene Earth - hothouse, icehouse, and impacts, Volume 452, Geological Society of America, p. 169-178.

Miller, K. G., Browning, J. V., Aubry, M. P., Wade, B. S., Katz, M. E., Kulpecz, A. A., and Wright, J. D., 2008, Eocene-Oligocene global climate and sea-level changes: St. Stephens Quarry, Alabama:

Geological Society of America Bulletin, v. 120, no. 1-2, p. 34-53.

Moncrieff, A. C. M., 1989, Classification of poorly-sorted sedimentary rocks: Sedimentary Geology, v. 65 , no. 1-2, p. 191-194.

Murray, R. W., Miller, D. J., and Kryc , K. A., 2000, Analysis of major and trace elements in rocks, sediments, and interstitial waters by inductively coupled plasma-atomic emission spectrometry (ICPAES): Texas A\&M University.

Nesbitt, H. W., and Young, G. M., 1982, Early Proterozoic climates and plate motions inferred from major element chemistry of lutites: Nature, v. 299, no. 21, p. 715-717.

Nesbitt, H. W., and Young, G. M., 1996, Petrogenesis of sediments in the absence of chemical weathering: effects of abrasion and sorting on bulk composition and mineralogy, Sedimentology, v. 43, p. 341-358.

Ollier, G., and Mathis, B., 1991, Lithologic Interpretation from Geophysical Logs in Holes 737B, 738C, 739C, and 742A, Proceedings of the Ocean Drilling Program, volume 119. U.S. Government Printing Office, College Station, Texas.

Pagani, M., Huber, M., Liu, Z., Bohaty, S. M., Henderiks, J., Sijp, W., Krishnan, S., and DeConto, R. M., 2011, The role of carbon dioxide during the onset of Antarctic glaciation: Science, v. 334, no. 6060, p. 1261-1264.

Pälike, H., Norris, R. D., Herrle, J. O., Wilson, P. A., Coxall, H. K., Lear, C. H., Shackleton, N. J., Tripati, A. K., and Wade, B. S., 2006, The heartbeat of the Oligocene climate system: Science, v. 314, no. 5807, p. 1894-1898.

Passchier, S., 2000, Sedimentology, mineralogy and geochemistry of the Sirius Group and other Cenozoic glacigenic sediments from Antarctica : implications for climate and ice sheet history [Ph.D.: Ohio State University, $360 \mathrm{p}$.

Passchier, S., O'Brien, P. E., Damuth, J. E., Januszczak, N., Handwerger, D. A., Whitehead, J. M., 2003, Pliocene-Pleistocene glaciomarine sedimentation in eastern Prydz Bay and development of the Prydz trough-mouth fan, ODP Sites 1166 and 1167, East Antarctica, Marine Geology, 199, 3, p. 279305.

Passchier, S., Bohaty, S. M., Jiménez-Espejo, F., Pross, J., Röhl, U., van de Flierdt, T., Escutia, C., and Brinkhuis, H., 2013, Early Eocene to middle Miocene cooling and aridification of East Antarctica: Geochemistry, Geophysics, Geosystems, v. 14, no. 5, p. 1399-1410.

Passchier, S., and Krissek, L. A., 2008, Oligocene-Miocene Antarctic continental weathering record and paleoclimatic implications, Cape Roberts drilling project, Ross Sea, Antarctica: Palaeogeography, Palaeoclimatology, Palaeoecology, v. 260, no. 1, p.30-40. 
Pearson, P. N., Foster, G. L., and Wade, B. S., 2009, Atmospheric carbon dioxide through the EoceneOligocene climate transition: Nature, v. 461, no. 7267, p. 1110-1113.

Persico, D., Fioroni, C., and Villa, G., 2012, A refined calcareous nannofossil biostratigraphy for the middle Eocene-early Oligocene Southern Ocean ODP sites: Palaeogeography, Palaeoclimatology, Palaeoecology, v. 335-336, p. 12-23.

Peters, S. E., Carlson, A. E., Kelly, D. C., and Gingerich, P. D., 2010, Large-scale glaciation and deglaciation of Antarctica during the Late Eocene: Geology, v. 38, no. 8, p. 723-726.

Plancq, J., Mattioli, E., Pittet, B., Simon, L. and Grossi, V., 2014, Productivity and sea-surface temperature changes recorded during the late Eocene-early Oligocene at DSDP Site 511 (South Atlantic): Palaeogeography, Palaeoclimatology, Palaeoecology, v. 407, p. 34-44.

Pross, J., Contreras, L., Bijl, P. K., Greenwood, D. R., Bohaty, S. M., Schouten, S., Bendle, J. A., Röhl, U., Tauxe, L., Raine, J. I., Huck, C. E., van de Flierdt, T., Jamieson, S. S., Stickley, C. E., van de Schootbrugge, B., Escutia, C., Brinkhuis, H., and Integrated Ocean Drilling Program Expedition, S., 2012, Persistent near-tropical warmth on the Antarctic continent during the early Eocene epoch: Nature, v. 488, no. 7409 , p. 73-77.

Pusz, A. E., Miller, K. G., Wright, J. D., Katz, M. E., Cramer, B. S. and Kent, D. V., 2009, Stable isotopic response to late Eocene extraterrestrial impacts, in Koeberl, C., and Montanari, A., ed., The late Eocene Earth - hothouse, icehouse, and impacts, Volume 452, Geological Society of America, p.83-95.

Robert, C. and Kennett, J. P., 1997, Antarctic continental weathering changes during EoceneOligocene cryosphere expansion: Clay mineral and oxygen isotope evidence: Geology (Boulder), v. 25, no. 7 , p. 587-590.

Rose, K. C., Ferraccioli, F., Jamieson, S. S. R., Bell, R. E., Corr, H., Creyts, T. T., Braaten, D., Jordan, T. A., Fretwell, P. T., and Damaske, D., 2013, Early East Antarctic Ice Sheet growth recorded in the landscape of the Gamburtsev Subglacial Mountains: Earth and Planetary Science Letters, v. 375, p. 112.

Sakai, H., and Keating, B., 1991, Paleomagnetism of Leg 119-Holes 737A, 738C, 742A, 745B, and 746A, Proceedings of the Ocean Drilling Program, volume 119. U.S. Government Printing Office, College Station, Texas.

Scher, H. D., Bohaty, S. M., Zachos, J. C., and Delaney, M. L., 2011, Two-stepping into the icehouse: East Antarctic weathering during progressive ice-sheet expansion at the Eocene-Oligocene transition: Geology, v. 39, no. 4, p. 383-386.

Sexton, P. F., Norris, R. D., Wilson, P. A., Palike, H., Westerhold, T., Röhl, U., Bolton, C. T., and Gibbs, S., 2011, Eocene global warming events driven by ventilation of oceanic dissolved organic carbon: Nature, v. 471, no. 7338, p. 349-352.

Sheldon, N. D., Retallack, G. J., and Tanaka, S., 2002, Geochemical climofunctions from North American soils and application to paleosols across the Eocene-Oligocene boundary in Oregon: The Journal of Geology, v. 110, p. 687-696.

Shipboard Scientific Party, 2001, Site 1166: Proceedings of the Ocean Drilling Program, Initial Reports volume 188, U.S. Government Printing Office, College Station, Texas. 
Sijp, W. P., England, M. H., and Huber, M., 2011, Effect of the deepening of the Tasman Gateway on the global ocean: Paleoceanography, v. 26, no. 4, p. n/a-n/a.

Steinthorsdottir, M., Porter, A. S., Holohan, A., Kunzmann, L., Collinson, M., and McElwain, J. C., 2016, Fossil plant stomata indicate decreasing atmospheric $\mathrm{CO}_{2}$ prior to the Eocene-Oligocene boundary, Climate of the Past, v. 12, p. 439-454, doi:10.5194/cp-12-439-2016.

Stickley, C. E., Brinkhuis, H., Schellenberg, S. A., Sluijs, A., Röhl, U., Fuller, M., Grauert, M., Huber, M., Warnaar, J., and Williams, G. L., 2004, Timing and nature of the deepening of the Tasmanian Gateway: Paleoceanography, v. 19, no. 4, p. n/a-n/a.

Stocchi, P., Escutia, C., Houben, A. J. P., Vermeersen, B. L. A., Bijl, P. K., Brinkhuis, H., DeConto, R. M., Galeotti, S., Passchier, S., Pollard, D. and Expedition 318 Scientists , 2013, Relative sea-level rise around East Antarctica during Oligocene glaciation: Nature Geoscience, v. 6, no. 5, p. 380-384.

Strand, K., Passchier, S., and Näsi, J., 2003, Implications of quartz grain microtextures for onset Eocene/Oligocene glaciation in Prydz Bay, ODP Site 1166, Antarctica: Palaeogeography, Palaeoclimatology, Palaeoecology, v. 198, no. 1-2, p. 101-111.

Thiry, M., 2000, Palaeoclimatic interpretation of clay minerals in marine deposits: an outlook from the continental origin: Earth-Science Reviews, v. 49, no. 1-4, p. 201-221.

Thomson, S. N., Reiners, P. W., Hemming, S. R., and Gehrels, G. E., 2013, The contribution of glacial erosion to shaping the hidden landscape of East Antarctica: Nature Geoscience, v. 6, no. 3, p. 203-207.

Tochilin, C. J., Reiners, P. W., Thomson, S. N., Gehrels, G. E., Hemming, S. R., and Pierce, E. L., 2012, Erosional history of the Prydz Bay sector of East Antarctica from detrital apatite and zircon geoand thermochronology multidating: Geochemistry, Geophysics, Geosystems, v. 13, no. 11, p. n/a-n/a.

Truswell, E. M., 1991, Data report: palynology of sediments from Leg 119 drill sites in Prydz Bay, East Antarctica, Proceedings of the Ocean Drilling Program, volume 119. U.S. Government Printing Office, College Station, Texas, p. 941-945.

van de Flierdt, T., Hemming, S. R., Goldstein, S. L., Gehrels, G. E., and Cox, S. E., 2008, Evidence against a young volcanic origin of the Gamburtsev Subglacial Mountains, Antarctica: Geophysical Research Letters, v. 35, no. 21.

Vandenberghe, N., Hilgen, F. J., Speijer, R. P., Ogg, J. G., Gradstein, F. M., Hammer, O., Hollis, C. J. and Hooker J. J., 2012, Chapter 28 - The Paleogene Period, in Gradstein, F. M., Schmitz, M. D. and Ogg, J. G., The Geologic Time Scale: Elsevier, Boston, p. 855-921.

Volpi, V., Rebesco, M. and Diviacco, P., 2009, New insights in the evolution of Antarctic glaciation from depth conversion of well-log calibrated seismic section of Prydz Bay: International Journal of Earth Sciences, v. 98, no. 8, p. 1991-2007.

Vonhof, H. B., Smit, J., Brinkhuis, H., Montanari, A., and Nederbragt, A. J., 2000, Global cooling accelerated by early late Eocene impacts?: Geology, v. 28, no. 8, p. 687-690.

Wade, B. S., Houben, A. J. P., Quaijtaal, W., Schouten, S., Rosenthal, Y., Miller, K. G., Katz, M. E., Wright, J. D., and Brinkhuis, H., 2012, Multiproxy record of abrupt sea-surface cooling across the Eocene-Oligocene transition in the Gulf of Mexico: Geology, v. 40, no. 2, p. 159-162.

Warnaar, J., 2006, Climatological implications of Australian-Antarctic separation [Ph.D. Thesis], Utrecht University. 
Wei, W., and Thierstein, H. R., 1991, Upper Cretaceous and Cenozoic Calcareous Nannofossils of the Kerguelen Plateau (Southern Indian Ocean) and Prydz Bay (East Antarctica), Proceedings of the Ocean Drilling Program, volume 119. U.S. Government Printing Office, College Station, Texas.

Wilson, D. S., Jamieson, S. S. R., Barrett, P. J., Leitchenkov, G., Gohl, K., and Larter, R. D., 2012, Antarctic topography at the Eocene-Oligocene boundary: Palaeogeography, Palaeoclimatology, Palaeoecology, v. 335-336, p. 24-34.

Zachos, J. C., Quinn, T. M., and Salamy, K. A., 1996, High-resolution (104 years) deep-sea foraminiferal stable isotope records of the Eocene-Oligocene climate transition: Paleoceanography, $v$. 11 , no. 3, p. 251-266.

Zachos, J.C., Opdyke, B.N., Quinn, T.M., Jones, C.E. and Halliday, A.N., 1999. Early cenozoic glaciation, antarctic weathering, and seawater $87 \mathrm{Sr} / 86 \mathrm{Sr}$ : is there a link?: Chemical Geology, v. 161, no. 1 , p. $165-180$.

Zachos, J., and Kump, L., 2005, Carbon cycle feedbacks and the initiation of Antarctic glaciation in the earliest Oligocene: Global and Planetary Change, v. 47, no. 1, p. 51-66. 


\section{FIGURES AND CAPTIONS}

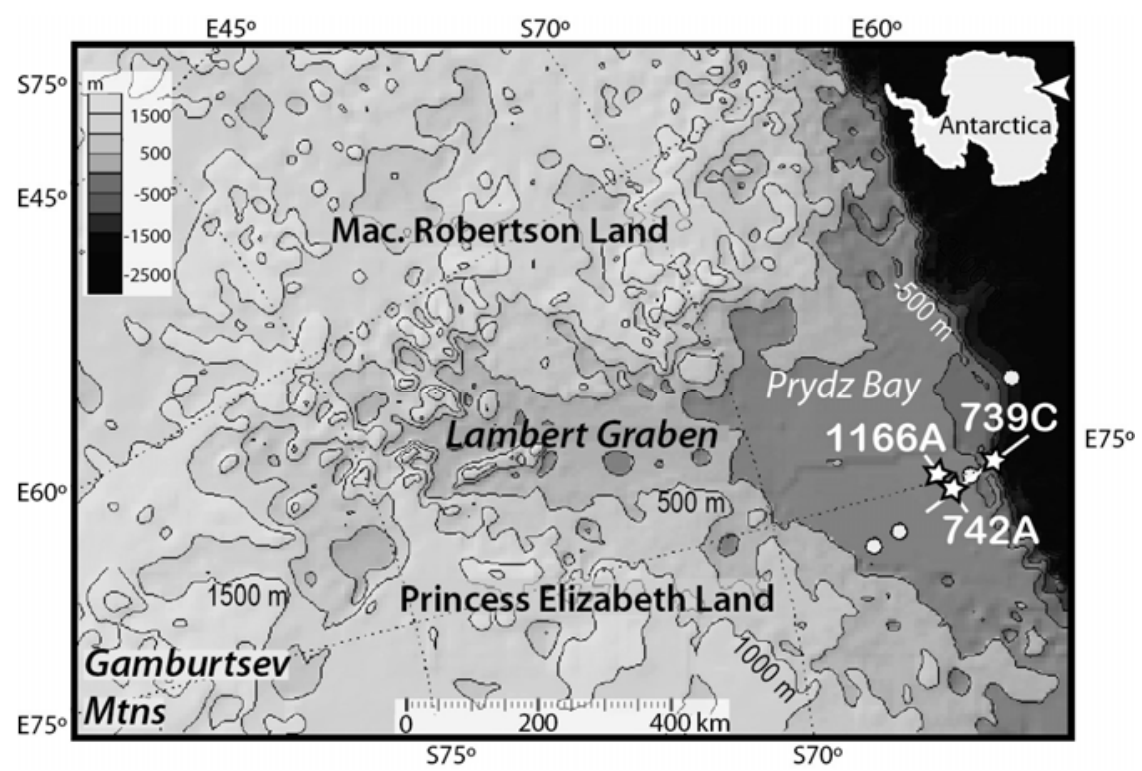

Figure 1. Locations of drillholes in Prydz Bay, East Antarctica, projected onto the reconstructed topography of Wilson et al. (2012) for the Eocene-Oligocene boundary. Drillholes discussed in this paper are indicated by a star. Circles represent other drillholes not discussed in the text. The white lines indicate the approximate positions of the interpreted seismic line segments displayed in Figure 2. 


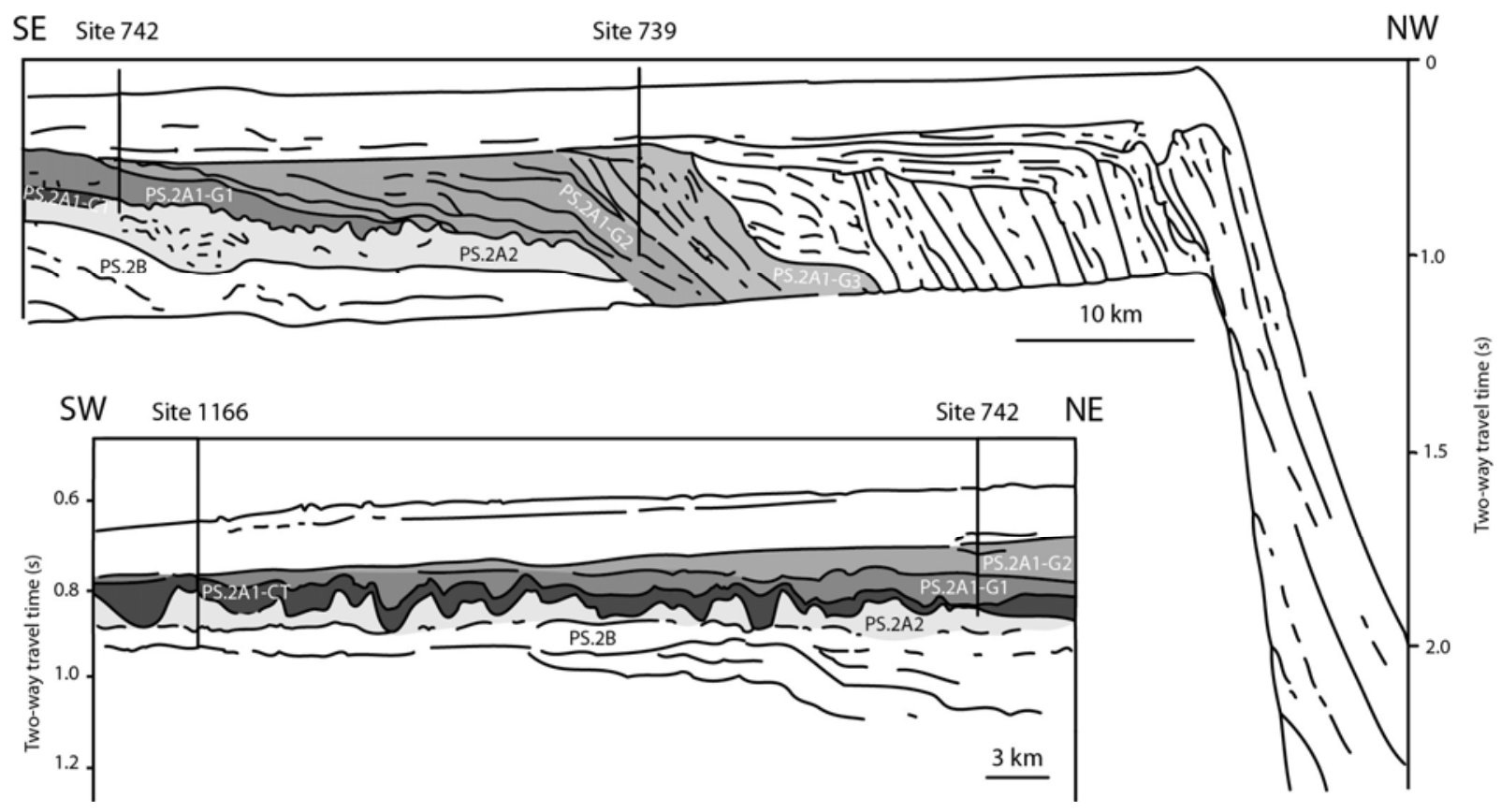

Figure 2. Interpretation of seismic line segments running from continental shelf to continental slope (upper) and across the shelf (lower). The labeling of the seismic units is according to Cooper et al. (1991) and Erohina et al. (2004). Note that Sites 739, 742, and 1166 penetrate consecutively deeper stratigraphic sections. 


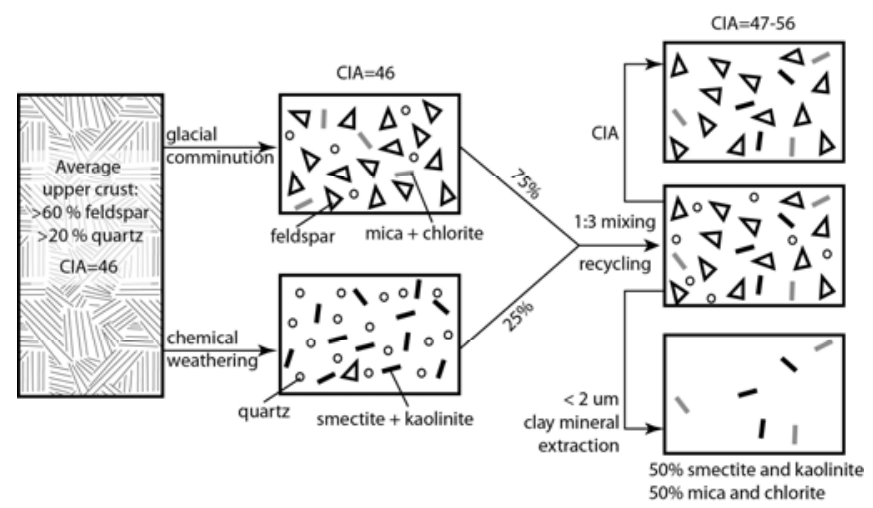

Figure 3. The Earth's upper crust contains on average more than $60 \%$ feldspars and more than 20\% quartz (Nesbitt and Young, 1982). Silicate weathering under elevated temperature and humidity leads to the transformation of feldspars to clay minerals (rich in $\mathrm{Al}$ ) and the release of cations (primarily $\mathrm{Ca}, \mathrm{Na}, \mathrm{K}$ ), whereas quartz ( $\mathrm{Si}$ ) is largely preserved. The cation ratios within the CIA reflect both feldspar preservation and formation of clay minerals in the bulk sediment and disregard the presence of quartz. Clay minerals are extracted from the $<2 \mu \mathrm{m}$ fraction for mineralogical analysis (right side of figure). Due to the small percentage of $<2 \mu \mathrm{m}$ sediment fraction produced through glacial comminution (left side of figure) the detrital clay minerals in the fine fraction are easily swamped by the incorporation of recycled weathered material. In contrast, the CIA is a sensitive recorder of the influx of physically eroded material because it is applied to the bulk sediment. 

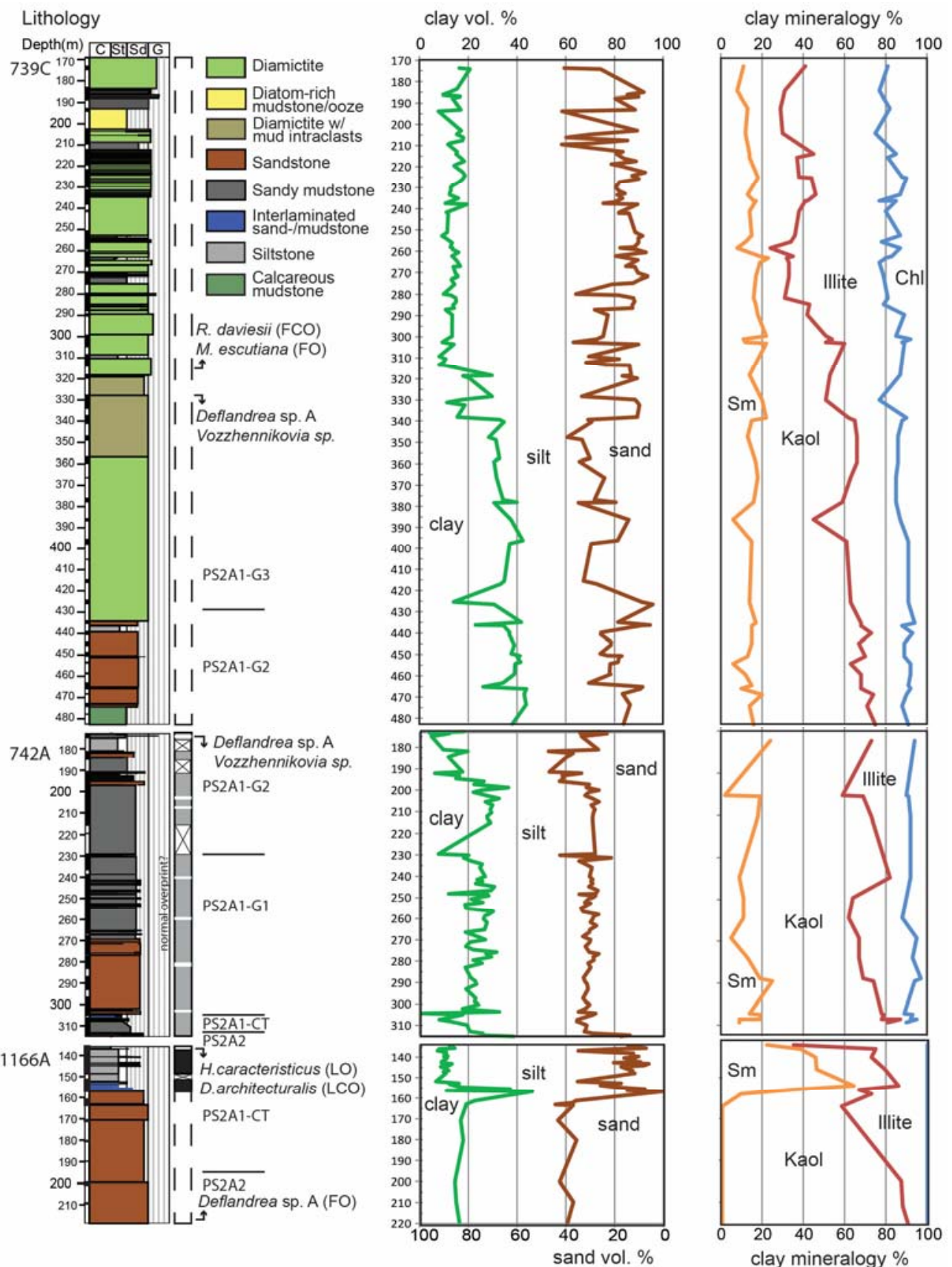

Figure 4. Lithostratigraphic summary for Holes 739C, 742A, and 1166A and stacked area charts of particle size distribution and clay mineral abundance. Core recovery is indicated with black bars next to the depth scale. Cores were logged according to a common lithostratigraphic scheme. Lithological codes $\mathrm{C}$, St, Sd, and $\mathbf{G}$ refer to clay, silt, sand and gravel respectively. Detailed logs are provided in Supplementary Materials. Percentage sand, silt and clay were calculated from laser particle size analysis. The clay mineralogy for Sites 739 and 742 is taken from Hambrey et al. (1991). The clay mineral abundances for Site 1166 were taken from Forsberg et al. (2008) and normalized to include only smectite, kaolinite, illite, and chlorite. 


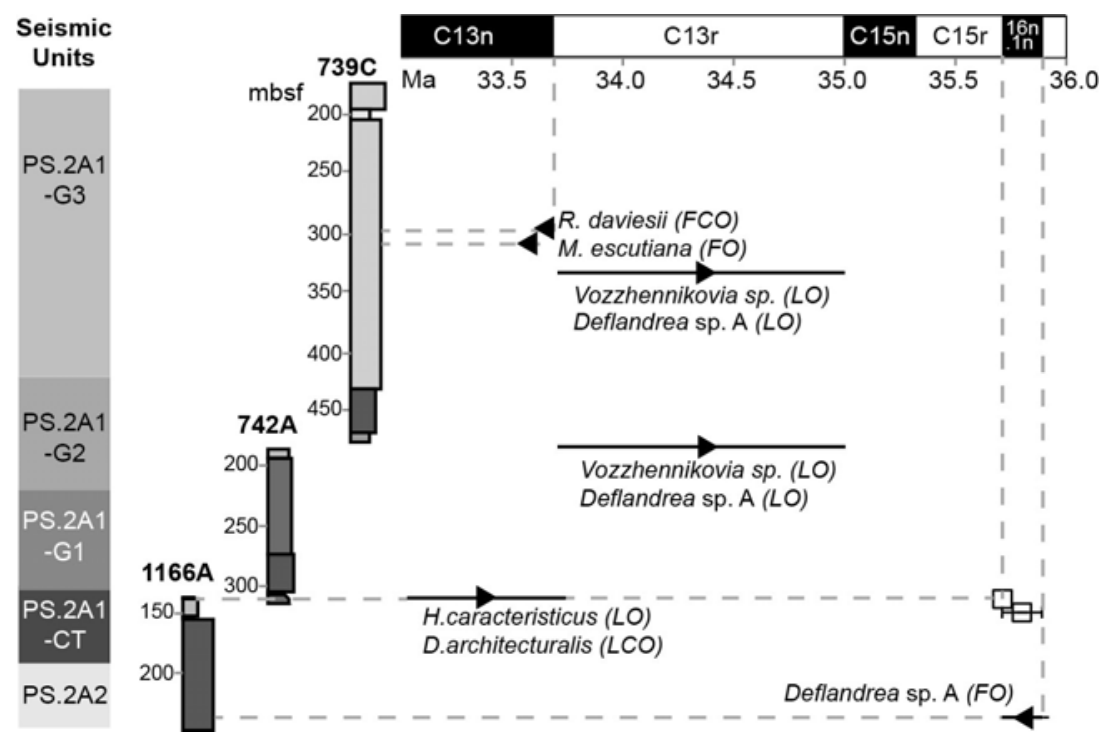

Figure 5. Age model for Holes 739C, 742A and 1166A. Superposition of stratigraphy in drillholes is derived from tracing seismic units according to Cooper et al. (1991b) and Erohina et al. (2004). The compiled biostratigraphy is in agreement with the superposition model (see text for details). Limited magnetostratigraphic correlations for Hole 1166A are according to Florindo et al. (2003). 


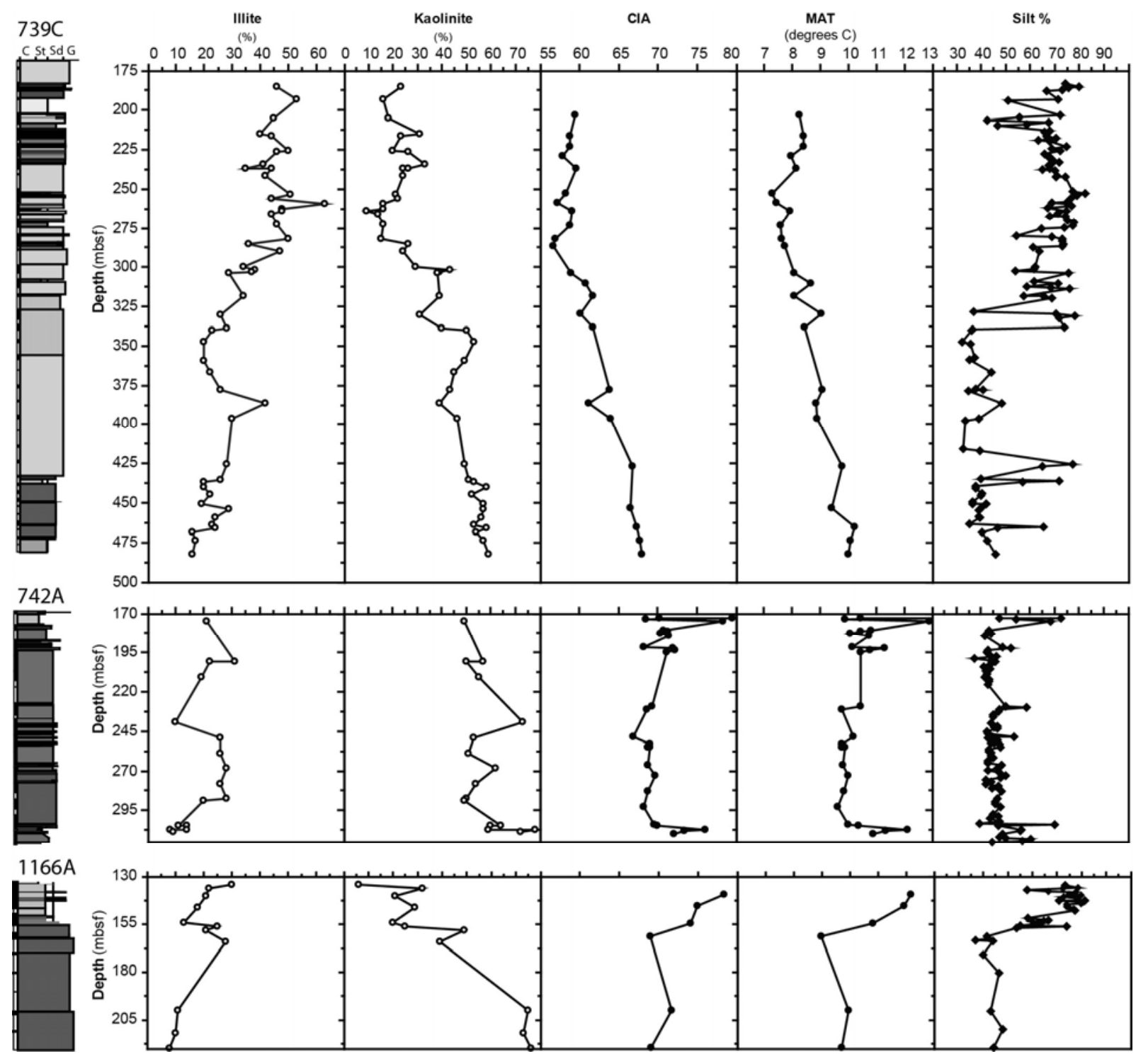

Figure 6. Percentage illite and kaolinite (from Hambrey et al., 1991; Forsberg et al., 2008), CIA (following Nesbitt and Young, 1982), MAT calculated using the S-index (following Sheldon et al., 2002), and percentage silt $(2-63 \mu \mathrm{m})$ in the matrix $(<2 \mathrm{~mm})$ of the sediment. Lithological codes $\mathrm{C}, \mathrm{St}$, Sd, and $\mathrm{G}$ refer to clay, silt, sand and gravel respectively. Detailed logs are provided in Supplemental Materials. 

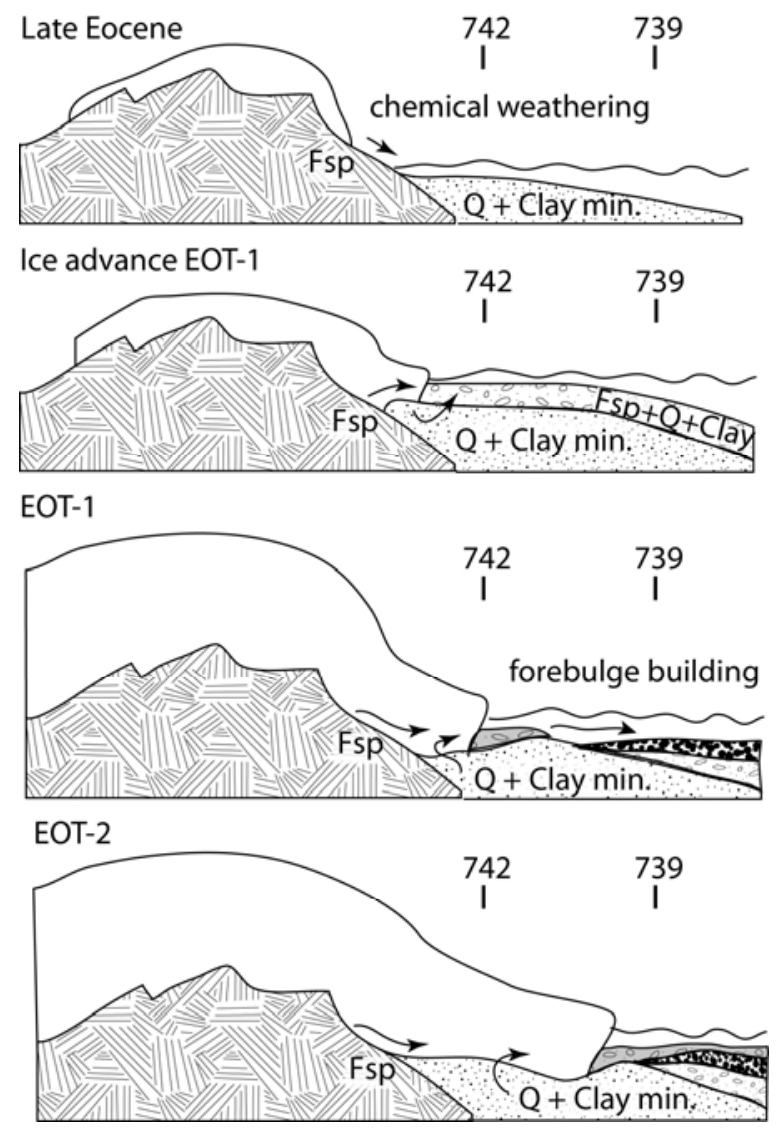

Figure 7. Depositional model for Prydz Bay during the Eocene-Oligocene transition. $F$ sp=feldspar; $Q=$ quartz; Clay min.=clay minerals; $E O T=$ Eocene-Oligocene Transition. The legend for the lithological patterns is the same as in Figure 8. 


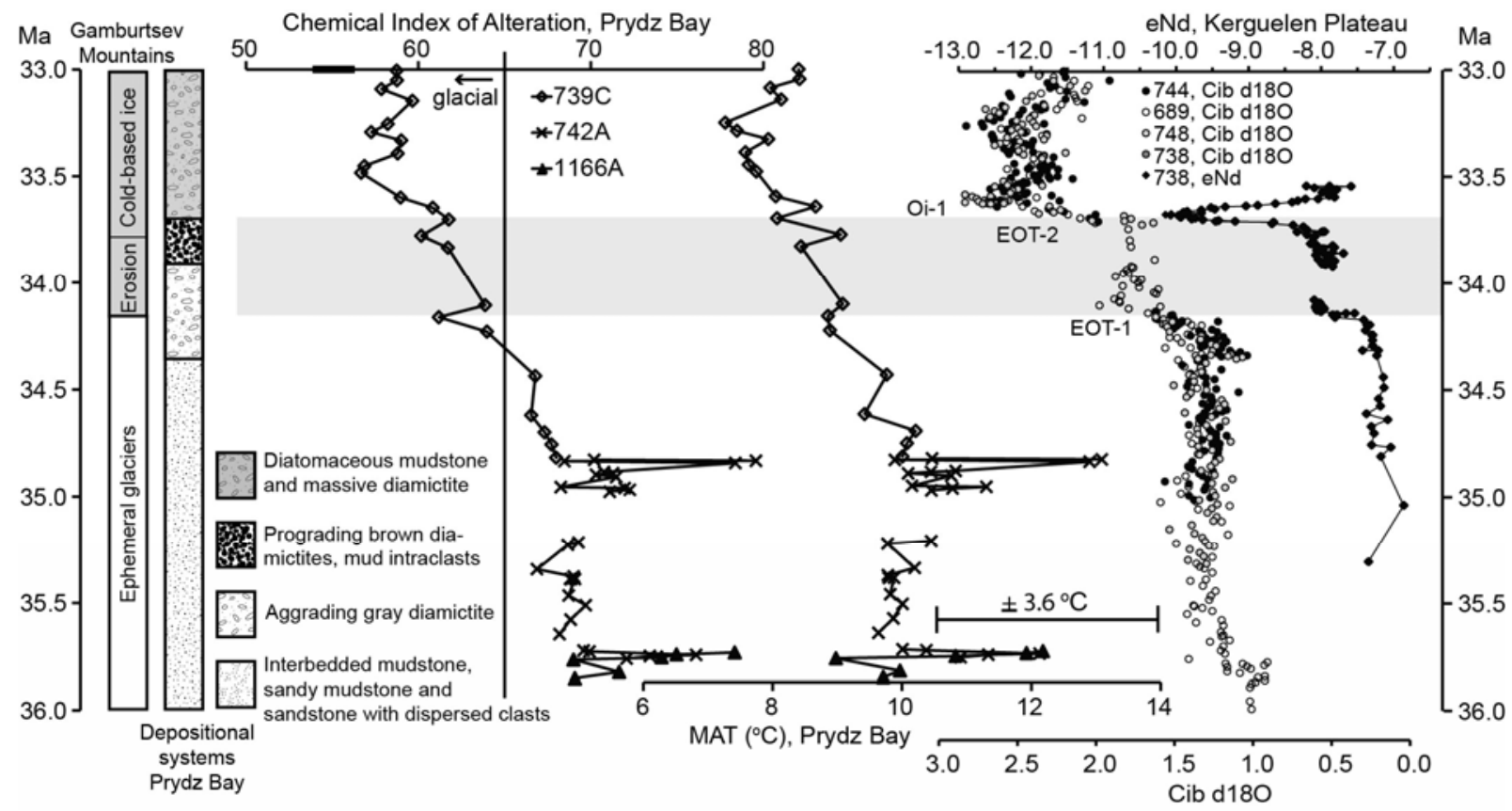

Figure 8. CIA values (Nesbitt and Young, 1982) and MAT calculated using the S-index (Sheldon et al., 2002) and geomorphological evidence from the Gamburtsev Mountains plotted on a linear age model. The timing of the erosion of the valleys off the Gamburtsev Mountains (Rose et al., 2013) has been tied to detrital geochronologic and thermochronologic datasets from Sites 739 and 1166. Reviewed in our new age model, these datasets document low erosion rates in Upper Eocene ( 35.9-35.7 Ma) strata between $\sim 240$ and 140 mbsf in Hole 1166A (Cox et al., 2010; Thomson et al., 2013) and a shift in Apatite Fission Track (APT) ages between 386 and 330 mbsf (34.2-33.8 Ma) in Hole 739C linked to enhanced erosion in the hinterland of Prydz Bay (Tochilin et al., 2012). The lithostratigraphic summary is discussed in the text and seismic stratigraphic codes are plotted alongside the composite lithostratigraphic column. Benthic foraminiferal (Cibicidoides) oxygen isotope data are from southern high latitude sites (Diester-Haass \& Zahn, 1996; Zachos et al., 1996, Vonhof et al., 2000, Scher et al., 2011; Bohaty et al., 2012). The epsilon Neodymium (eNd) data are from Scher et al. (2011). The grey bar marks the Eocene-Oligocene Transition (EOT) interval and the black bar on the CIA axis represents the range of values for Quaternary diamicts in Prydz Bay. CIA values lower than 65 are interpreted as sediment delivery dominated by glacial rock flour into Prydz Bay (see main text). 